\title{
Research Paper: The Early Prelinguistic Skills in Iranian Infants and Toddlers
}

\author{
Narges Bayat ${ }^{1}$ (D), Atieh Ashtari ${ }^{1 *}$ (D), Mohsen Vahedi ${ }^{2}$ (iD)
}

1. Department of Speech Therapy, University of Social Welfare and Rehabilitation Sciences, Tehran, Iran.

2. Department of Biostatistics and Epidemiology, Paediatric Neurorehabilitation Research Centre, University of Social Welfare and Rehabilitation Sciences, Tehran, Iran.

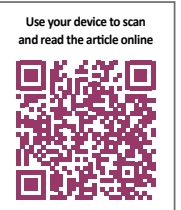

ditation Bayat N, Ashtari A, Vahedi M. The Early Prelinguistic Skills in Iranian Infants and Toddlers. Iranian Rehabilitation Journal. 2021; 19(4):441-454. http://dx.doi.org/10.32598/irj.19.4.1605.1

http://dx.doi.org/10.32598/irj.19.4.1605.1

Article info:

Received: 20 Sep 2021

Accepted: 20 Oct 2021

Available Online: 01 Dec 2021

\section{Keywords:}

Prelinguistic skills, Communication, Children, Gesture, Eye contact, Vocalization

\section{A B ST RACT}

Objectives: The prelinguistic skills which pave the way for language development have always been an area of research in the Speech Therapy field. Although studying these skills is important, there is a study gap among Persian children. Therefore, this study explored prelinguistic skills among a sample of Persian-speaking children aged 6 to 24 months and made a comparison between different age groups. We also studied the effects of gender and family history of speech-language disorders on children's prelinguistic abilities.

Methods: In the present study, 277 mothers of Iranian Persian-speaking children aged 6 to 24 months were asked to fill a research-made checklist that evaluated the prelinguistic skills of their children. This study was cross-sectional and was conducted in Tehran City, Iran, in 2021. Children's abilities in different age groups were compared using the analysis of variance (ANOVA), Scheffe test, the Kruskal-Wallis test, and the post-hoc test. The differences between the total scores of the two genders were also determined using the Mann-Whitney U test.

Results: Comparing the prelinguistic skills in different age groups indicated a statistically significant increase in the scores as children grow up. Children with a positive family history of speech-language disorders scored lower on the checklist than the others $(91.03 \pm 17.37)$. Furthermore, there were statistically significant differences between the two genders in developing gesture, vocalization, first words, social interaction, imitation, and play; girls had higher scores.

Conclusion: Based on the studies conducted in different countries, prelinguistic skills develop as children grow up; these skills facilitate language acquisition and other social skills. The present study also demonstrated the development of these skills alongside children's development. This similarity between Persian-speaking children and other children from different cultures and languages, as well as better performance in children with a negative family history of speech-language impairments, confirm the role of genetic factors in children's development. Moreover, the differences in the development of some prelinguistic skills between girls and boys reveal the impact of various factors, such as social factors, on prelinguistic skills development.

\section{* Corresponding Author:}

Atieh Ashtari, PhD.

Address: Department of Speech Therapy, University of Social Welfare and Rehabilitation Sciences, Tehran, Iran

Tel: +98 (21) 222180043

E-mail: at.ashtari@uswrac.ir 


\section{Highlights}

- Six to 24 months old children have different abilities in terms of prelinguistic skills.

- There are differences between girls and boys regarding prelinguistic skills, such as gesture, vocalization, first word, social interaction, imitation, and play.

- Children develop their communicational skills in the prelinguistic stage as they grow up.

- Positive family history of speech-language disorders affects children's performance in the prelinguistic stage.

\section{Plain Language Summary}

Children develop prelinguistic skills before learning to use language. Prelinguistic skills are the only ways that children can communicate with their parents before expressing their first words. For example, pointing at something is a prelinguistic skill, which provides a foundation for language learning. Studying these skills is very important because it gives us more information about the prerequisites of language learning and determining communication deficits at an early age. This study focused on the development of prelinguistic skills in Persian children aged 6 to 24 months. We found that these skills develop as children age and become more complex. Based on the results, a positive history of speech or language-related disorders in the family affects children's prelinguistic skills. Also, we found some differences between girls and boys in developing these skills. Our findings provided helpful information about prelinguistic skills that can spot children at risk of communication disorders.

\section{Introduction}

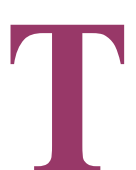

he prelinguistic stage is between 1 month and 18 or 24 months of age [1] This period is before the language emergence phase. Communication skills developing in the prelinguistic stage are nonverbal skills that form the main communication ways of children at this period. This phase involves a subtle but systematic developmental transition as children move from the prelinguistic to the linguistic stage. These skills serve as a foundation and predictor for later language development. Therefore, they are important subjects to study in this stage [2,3].

The prelinguistic skills that develop before language acquisition can be classified as means of communication (e.g., eye contact, gestures, vocalization, first words, and facial expressions) [4-9], and communicative functions (e.g., behavior regulation, joint attention, and social interaction [10]. Furthermore, some prelinguistic skills have cognitive bases, like imitation, object permanence, and playing [11-13].

Prelinguistic skills are essential in children's development because of their association with language acquisition $[2,3]$. These skills are the basis of language development, as children with limited prelinguistic skills may face difficulties in language acquisition [14]. As indicated in the study conducted by Luke et al., lower pointing gestures at 12 and 14 months are associated with language development delays [15]. Besides, children's communication abilities in this stage predict their later language development [16]. That is why some researchers name prelinguistic skills as language predictors $[17,18]$. For instance, the predictive value of babbling on subsequent language acquisition has been mentioned in Fasolo, Majorano, and Dodorico's study. Based on their findings, late talkers have limited phonetic complexity and a lower rate of babbling than typically-developing children [19].

There are some factors, such as family history and gender, that might affect the children's communication skills development [20, 21]. Family history of speech-language disorders is one of the risk factors for these impairments in children up to five years old [22]. Sunderajan and Kanhere [23], Molini-Avejonas et al. [22], Saeed et al. [24], and Conti-Ramsden and Durkin [25] highlighted the higher prevalence of speech-language impairments in children with positive family history. Twin studies [26] and family aggregation studies [27], as well as genetic linkage analyses [28], provided strong evidence of running speech-language impairments in families.

While girls and boys are similar at birth, there are differences in their verbal abilities under the age of 3 [21]. For 
instance, girls have a larger vocabulary than boys at 18 to 24 months [29]. Some researchers discuss the influence of social factors on cognitive and language domains [3033]; however, others debate on the greater male variability hypothesis (i.e., greater variability among males in intelligence compared to females), which might lead to different language abilities in boys [34, 35]. Also, after the discovery of the first gene connected with speech and language disorders, the FOXP2 gene [36], a considerable number of studies focused on gender differences as genetic factors involved in speech and language developments [37-39]. For instance, in a review article, Wermke et al. concluded that the difference between hormones in boys and girls leads to faster language development in girls [40].

Few studies have been published about Persian children's prelinguistic skills. Most of these studies only focus on the expressive language and first words [4144]. For example, Mahmoudi Bakhtiyari et al. studied expressive lexicon size in Persian children aged 18 to 36 months [45]. Some studies have focused on only one prelinguistic skill $[46,47]$, and some had a limited number of participants $[48,49]$.

The relation between prelinguistic and linguistic stages increases the significance of studying the prelinguistic skills [17]. Despite the importance of these skills, there are limited studies focused on prelinguistic skills and comparing them in different age groups in Persianspeaking children. The present study aimed to investigate the prelinguistic skills in Persian-speaking children aged 6 to 24 months and compare these children within different age groups and genders. We also studied the effects of family history of speech-language impairments.

\section{Materials and Methods}

This cross-sectional study was conducted in Tehran City, Iran, in 2021. We included 277 Persian-speaking children (124 girls and 153 boys) aged between 6 and 24 months (Mean \pm SD: $15.81 \pm 5.9$ months). The children were independently grouped according to their ages. In this study, 49 children aged 6-9 months, 53 children aged 10-12 months, 73 children aged 13-18 months, and 102 children aged 19-24 months. A convenient sampling method was used for the selection of the study participants from Tehran, Iran. The inclusion criteria were normal mental and physical development, having no history or symptoms of neurological problems, brain damage, seizures, or any other disorders, having literate mothers, and no divorced parents. The Persian version of the ages and stages questionnaire was used to check children's developmental status. It is a reliable and valid tool for assessing the physical and mental development of Persian children [50]. Mothers of the children who withdrew from the study were excluded. After explaining the aim and method of the research, mothers of the children interested in participating were checked regarding the inclusion criteria. Those mothers whose children were eligible to participate in this study provided written informed consent. The researcher-made checklist was sent to the mothers by Email or social media apps like WhatsApp. All participants who received the checklist completed it. The research protocol was approved by the Ethics Committee of the University of Social Welfare and Rehabilitation Sciences, Tehran, Iran (Code: IR.USWR. REC.1400.025). The characteristics of the children are demonstrated in Table 1.

In the present study, the mothers were asked to fill the communication skills checklist, which is a researcher-made checklist, and answer some questions about family history of speech-language disorders. This checklist evaluates the means of communication (i.e., eye contact, gestures, vocalization, first words, and facial expressions), communicative functions (i.e., behavior regulation, joint attention, and social interaction), and prelinguistic skills with cognitive bases (i.e., imitation and object permanence). The checklist contains 36 items (33 scored on a 3-point Likert-type scale, and three scored on a 5-point Likert-type scale), according to the psychometric properties of the researchermade checklist, which was determined before the present study. It is a reliable and valid instrument. All items had the Content Validity Ratio (CVR) higher than 0.79 and the Content Validity Index (CVI) of higher than 0.62. Based on the validity of the age groups, the results of the communication skills checklist demonstrated significant differences between the four age groups. Moreover, based on the previous study, the checklist demonstrated a high association with the "childhood nonverbal communication scale" [51, 52]. The internal consistency determined by the Cronbach $\alpha$ was 0.952 for all the 3-point Likert scored items and was 0.857 for the 5-point Likert scored items. This result indicated a good correlation between these items. The test-retest reliability coefficient was also calculated regarding 50 mothers who filled the checklist for the second time about two weeks later. According to the intraclass correlation coefficient (ICC), the checklist demonstrated excellent reliability $(\mathrm{ICC}=0.933, \mathrm{P}<0.001)$ [52].

After the data gathering, the statistical analysis was performed using the SPSS v. 25. Analysis of variance (ANOVA), Scheffé test [53], the Kruskal-Wallis, and the post-hoc test [54] were used to compare the children's ability in the four above-mentioned age groups. The dif- 
Table 1. Characteristics of the participants (family history of speech-language disorders) $(\mathrm{N}=277$ )

\begin{tabular}{|c|c|c|c|c|}
\hline \multirow{2}{*}{\multicolumn{2}{|c|}{ Variables }} & \multicolumn{3}{|c|}{ No.(\%) } \\
\hline & & Negative & Positive & Total \\
\hline \multirow{2}{*}{ Participants' gender } & Girls & 112(90.3) & $12(9.7)$ & $124(44.8)$ \\
\hline & Boys & $124(81)$ & 29(19) & $153(55.2)$ \\
\hline \multirow{4}{*}{$\begin{array}{l}\text { Number of children in } \\
\text { each age group }\end{array}$} & 6-9 months & 45(91.8) & $4(8.2)$ & 49(17.69) \\
\hline & $10-12$ months & $47(88.7)$ & $6(11.3)$ & 53(19.13) \\
\hline & $13-18$ months & $64(87.7)$ & $9(12.3)$ & $73(26.35)$ \\
\hline & 19-24 months & $80(78.4)$ & $22(21.6)$ & $102(36.83)$ \\
\hline
\end{tabular}

Iranian Rehabilitation Journal

ference between the total scores of the two genders was also determined using the Mann-Whitney $U$ test.

\section{Results}

In the present research, 277 children aged between 6 and 24 months were studied. The results of the statistical analysis are described in the following. According to Table 2, the 2-way ANOVA test demonstrated lower scores of the communication skills checklist in children with a positive family history of speech-language impairments. Furthermore, the results illustrated the increase in the scores as children grow up. This increase is also demonstrated in the scores of gestures (Table 3 ) and first words (Table 4). Based on the results of the Scheffé test in Table 5, there were significant differences between the age groups.

The Kruskal-Wallis test showed a statistically significant difference in the score of each skill between the different age groups (i.e., eye contact $\chi^{2}(3)=15.941$,
$\mathrm{P}=0.001$; gestures $\chi^{2}(3)=160.141, \mathrm{P}=0.001$; vocalization $\chi^{2}(3)=124.231, \mathrm{P}=0.001$; first words $\chi^{2}(3)=179.094$, $\mathrm{P}=0.001$; facial expressions $\chi^{2}(3)=33.528, \mathrm{P}=0.001$; behavior regulation $\chi^{2}(3)=102.062, \mathrm{P}=0.001$; joint attention $\chi^{2}(3)=77.307, \mathrm{P}=0.001$; social interaction $\chi^{2}(3)=95.188$, $\mathrm{P}=0.001$; imitation $\chi^{2}(3)=128.707, \mathrm{P}=0.001$; object permanence $\chi^{2}(3)=132.283, \mathrm{P}=0.001$; play $\chi^{2}(3)=136.551$, $\mathrm{P}=0.001)$. According to the post-hoc test, gestures and first words are specifically different between the four age groups. In other words, the scores of these two skills are statistically different between 6 to 9 and 10 to 12,6 to 9 and 13 to 18,6 to 9 and 19 to 24,10 to 12 and 13 to 18 , 10 to 12 and 19 to 24 , and 13 to 18 and 19 to 24 months. The Kruskal-Wallis and the post-hoc tests results are presented in Table 6.

Based on the results of the Mann-Whitney $U$ test in Table 7, the standardized test statistics for eye contact, gestures, vocalization, first words, facial expressions,

Table 2. Results of 2-way ANOVA test showing the relation between family history, age, and total score of the communication skills checklist (family history of speech-language disorders)

\begin{tabular}{cccc}
\hline & & Mean \pm SD & \\
\cline { 2 - 4 } Age Groups (Month) & Negative & Positive & Total \\
\cline { 2 - 4 } $6-9$ & $65.66 \pm 12.81$ & $59 \pm 10.86$ & $65.12 \pm 12.69$ \\
$10-12$ & $82.46 \pm 10.87$ & $82.50 \pm 21$ & $82.47 \pm 12.12$ \\
\hline $13-18$ & $96.79 \pm 8.32$ & $88.11 \pm 9.71$ & $95.72 \pm 8.90$ \\
$19-24$ & $105.57 \pm 6.27$ & $100.90 \pm 8.91$ & $104.56 \pm 7.14$ \\
\hline Total & $90.98 \pm 17.45$ & $91.31 \pm 17.13$ & $91.03 \pm 17.37$ \\
\hline
\end{tabular}


Table 3. Results of 2-way ANOVA test showing the relation between family history, age, and gestures score (family history of speech-language disorders)

\begin{tabular}{cccc}
\hline & & Mean \pm SD & \\
\cline { 2 - 3 } Age Groups (Month) & Negative & Positive & Total \\
\hline $6-9$ & $11.73 \pm 3.01$ & $10.25 \pm 2.62$ & $11.61 \pm 2.99$ \\
$10-12$ & $16.82 \pm 3.30$ & $16.83 \pm 5.49$ & $16.83 \pm 3.54$ \\
$13-18$ & $21.20 \pm 2.16$ & $18.88 \pm 3.55$ & $20.91 \pm 2.47$ \\
$19-24$ & $22.46 \pm 1.84$ & $21.59 \pm 4.76$ & $22.27 \pm 1.91$ \\
\hline Total & $18.95 \pm 4.76$ & $19.19 \pm 4.58$ & $18.98 \pm 4.73$ \\
\hline
\end{tabular}

Iranian Rehabilitation Dourna

behavior regulation, joint attention, social interaction, imitation, object permanence, and play were respectively $-0.704,-2.621,-2.206,-3.624,-0.300,-1.468,-0.951$, $-2.154,-2.846,-1.162$, and -3.953 . P value was only lower than 0.05 in gesture, vocalization, first words, social interaction, imitation, and play skills.

\section{Discussion}

The present study aimed to assess prelinguistic skills in Persian-speaking children aged 6 to 24 months and compare the skills between different age groups and the two genders. Also, we studied the effects of family history of speech-language disorders on children's prelinguistic development. The prelinguistic skills assessed in this study were means of communication (i.e., eye contact, gestures, vocalization, first words, and facial expressions), communicative functions (i.e., behavior regulation, joint attention, and social interaction), and prelinguistic skills with cognitive bases (i.e., imitation and object permanence).

The analysis revealed the statistically significant differences between the scores of 6 to 9 months, 10 to 12 months, 13 to 18 months, and 19 to 24 months groups, indicating that these prelinguistic skills develop as children grow up.

According to the results, there is a difference in the frequency of eye contact between different age groups. These results are consistent with those of Brooks and Meltzoff [4], Dawson et al. [55], and Berger and Cunningham [56]. Eye contact, an essential skill affecting information processing, should be developed in children to facilitate learning [57].

According to our findings, gestures develop as children grow up. This increase in ability in the perception and expression of gestures from 6 to 24 months can be attrib-

Table 4. Results of 2-Way ANOVA test showing the relation between family history, age, and first words score (family history of speech-language disorders)

\begin{tabular}{cccc}
\hline & & Mean \pm SD & \\
\cline { 2 - 4 } Age Groups (Month) & Negative & Positive & Total \\
\hline $6-9$ & $9.42 \pm 9.42$ & $8 \pm 0.81$ & $9.30 \pm 2.05$ \\
$10-12$ & $11.63 \pm 2.64$ & $13.16 \pm 5.03$ & $11.81 \pm 2.98$ \\
$13-18$ & $14.43 \pm 2.27$ & $12.55 \pm 2.60$ & $14.20 \pm 2.38$ \\
$19-24$ & $18.51 \pm 1.92$ & $16.31 \pm 2.80$ & $18.03 \pm 2.31$ \\
\hline Total & $14.30 \pm 4.10$ & $14.21 \pm 3.97$ & $14.29 \pm 4.07$ \\
\hline
\end{tabular}


Table 5. Results of the Scheffé Test

\begin{tabular}{|c|c|c|c|c|}
\hline \multicolumn{2}{|c|}{ Age Groups (Month) } & \multirow{2}{*}{$\begin{array}{c}\text { Mean Difference } \\
-17.34\end{array}$} & \multirow{2}{*}{$\begin{array}{c}\text { Standard Error } \\
1.94\end{array}$} & \multirow{2}{*}{$\begin{array}{c}\mathbf{P} \\
<0.001\end{array}$} \\
\hline & 10 to 12 & & & \\
\hline $6-9$ & 13 to 18 & -30.60 & 1.81 & $<0.001$ \\
\hline & 19 to 24 & -39.44 & 1.70 & $<0.001$ \\
\hline \multirow{3}{*}{$10-12$} & 6 to 9 & 17.34 & 1.94 & $<0.001$ \\
\hline & 13 to 18 & -13.25 & 1.76 & $<0.001$ \\
\hline & 19 to 24 & -22.09 & 1.66 & $<0.001$ \\
\hline \multirow{3}{*}{$13-18$} & 6 to 9 & 30.60 & 1.81 & $<0.001$ \\
\hline & 10 to 12 & 13.25 & 1.79 & $<0.001$ \\
\hline & 19 to 24 & -8.84 & 1.50 & $<0.001$ \\
\hline \multirow{3}{*}{$19-24$} & 6 to 9 & 39.44 & 1.70 & $<0.001$ \\
\hline & 10 to 12 & 22.09 & 1.66 & $<0.001$ \\
\hline & 13 to 18 & 8.84 & 1.50 & $<0.001$ \\
\hline
\end{tabular}

Iranian Rehabilitation Journal

uted to mothers' performance. Mothers in the early years of their children's life usually use gesture-word combinations [58, 59]. Moreover, with the emergence of communicative functions in children, especially joint attention, the use of some direct gestures such as pointing increases since pointing is one of the most common forms of communication in joint attention [60, 61]. However, our findings of gestures are consistent with the studies conducted by Bates et al. [62], Crais et al. [63], Tomasello et al. [64], Masur et al. [58], and Iverson et al. [59]. Babaei et al. concluded that gestures remain stable in Iranian children from 12 to 18 months. This difference might be due to the small number of samples in that study [48].

There is a difference between the results of the age groups in vocalization. These findings are consistent with Davis and Macneilge's paper. According to their findings, children use labial and alveolar consonants more than the others in their primary babblings. As children develop, the consonants become more varied, and when they reach 14 to 20 months of age, they use different consonants like nasal consonants [65].

Based on the results, children express more words as they grow up, which is consistent with studies conducted by Brooks and Kempe [66], Mahmoudi Bakhtiyari et al. [45], and Tardif et al. [67]. Children's first words are important issues to be assessed in the prelinguistic stage. Surprisingly, children who were late to express first words were more at risk for future language problems than children who were not [68]. Vocabulary spurt, an acceleration in the rate of expressing new words, happens between 19 to 18 months of age $[69,70]$. The age of this apparent growth is also consistent with our findings.

The ability to express and perceive facial expressions and emotions are different between age groups. This finding is consistent with the studies conducted by Herba and Phillips [71], Cole [72], McClure [73], and Thompson [74].

Based on the results, there is a difference between the communicative functions scores in the age groups. Children's ability in response to and initiation of joint attention, behavioral regulation, and social interaction was different between the age groups, which is consistent with the studies conducted by Mundy et al. [75], Carpenter et al. [76], and Papousek [77]. However, the results are not consistent with Babaei et al.'s study because they consider the development of joint attention stable from 12 to 15 months of age. The difference is assumed to be due to the various methodologies [49].

The ability to imitate, which is the base of the mind theory [78], is different among the age groups. This finding is consistent with the papers published by Jones [79], Wang et al. [80], and Oostenbroek et al. [81]. The difference between the age groups in object permanence abil- 
Table 6. Results of the Kruskal-Wallis and Post Hoc Tests

\begin{tabular}{|c|c|c|c|c|c|}
\hline Skill & Test Statistics & Degrees of Freedom & $\mathbf{P}$ & Age Groups & Post Hoc Test \\
\hline \multirow{6}{*}{ Eye contact } & \multirow{6}{*}{15.941} & \multirow{6}{*}{3} & \multirow{6}{*}{$<0.001$} & 6 to $9-10$ to 12 & $<0.689$ \\
\hline & & & & 6 to $9-13$ to 18 & $<0.229$ \\
\hline & & & & 6 to $9-19$ to 24 & $<0.001$ \\
\hline & & & & 10 to $12-13$ to 18 & $<1.000$ \\
\hline & & & & 10 to $12-19$ to 24 & $<0.194$ \\
\hline & & & & 13 to $18-19$ to 24 & $<0.343$ \\
\hline \multirow{6}{*}{ Gestures } & \multirow{6}{*}{160.141} & \multirow{6}{*}{3} & \multirow{6}{*}{$<0.001$} & 6 to $9-10$ to 12 & $<0.001$ \\
\hline & & & & 6 to $9-13$ to 18 & $<0.001$ \\
\hline & & & & 6 to $9-19$ to 24 & $<0.001$ \\
\hline & & & & 10 to $12-13$ to 18 & $<0.001$ \\
\hline & & & & 10 to $12-19$ to 24 & $<0.001$ \\
\hline & & & & 13 to $18-19$ to 24 & $<0.021$ \\
\hline \multirow{6}{*}{ Vocalization } & \multirow{6}{*}{124.231} & \multirow{6}{*}{3} & \multirow{6}{*}{$<0.001$} & 6 to $9-10$ to 12 & $<0.052$ \\
\hline & & & & 6 to $9-13$ to 18 & $<0.001$ \\
\hline & & & & 6 to $9-19$ to 24 & $<0.001$ \\
\hline & & & & 10 to $12-13$ to 18 & $<0.073$ \\
\hline & & & & 10 to $12-19$ to 24 & $<0.001$ \\
\hline & & & & 13 to $18-19$ to 24 & $<0.001$ \\
\hline \multirow{6}{*}{ First words } & \multirow{6}{*}{179.094} & \multirow{6}{*}{3} & \multirow{6}{*}{$<0.001$} & 6 to $9-10$ to 12 & $<0.008$ \\
\hline & & & & 6 to $9-13$ to 18 & $<0.001$ \\
\hline & & & & 6 to $9-19$ to 24 & $<0.001$ \\
\hline & & & & 10 to $12-13$ to 18 & $<0.005$ \\
\hline & & & & 10 to $12-19$ to 24 & $<0.001$ \\
\hline & & & & 13 to $18-19$ to 24 & $<0.001$ \\
\hline \multirow{6}{*}{ Facial expressions } & \multirow{6}{*}{33.528} & \multirow{6}{*}{3} & \multirow{6}{*}{$<0.001$} & 6 to $9-10$ to 12 & $<0.877$ \\
\hline & & & & 6 to $9-13$ to 18 & $<0.001$ \\
\hline & & & & 6 to $9-19$ to 24 & $<0.001$ \\
\hline & & & & 10 to $12-13$ to 18 & $<0.020$ \\
\hline & & & & 10 to $12-19$ to 24 & $<0.004$ \\
\hline & & & & 13 to $18-19$ to 24 & $<1.000$ \\
\hline \multirow{6}{*}{ Behavior regulation } & \multirow{6}{*}{102.062} & \multirow{6}{*}{3} & \multirow{6}{*}{$<0.001$} & 6 to $9-10$ to 12 & $<0.002$ \\
\hline & & & & 6 to $9-13$ to 18 & $<0.001$ \\
\hline & & & & 6 to $9-19$ to 24 & $<0.001$ \\
\hline & & & & 10 to $12-13$ to 18 & $<0.001$ \\
\hline & & & & 10 to $12-19$ to 24 & $<0.001$ \\
\hline & & & & 13 to $18-19$ to 24 & $<1.000$ \\
\hline
\end{tabular}




\begin{tabular}{|c|c|c|c|c|c|}
\hline Skill & Test Statistics & Degrees of Freedom & $\mathbf{P}$ & Age Groups & Post Hoc Test \\
\hline \multirow{7}{*}{ Joint attention } & \multirow{7}{*}{77.307} & \multirow{7}{*}{3} & \multirow{7}{*}{$<0.001$} & 6 to $9-10$ to 12 & $<0.001$ \\
\hline & & & & 6 to $9-13$ to 18 & $<0.001$ \\
\hline & & & & 6 to $9-19$ to 24 & $<0.001$ \\
\hline & & & & & \\
\hline & & & & 10 to $12-13$ to 18 & $<0.256$ \\
\hline & & & & 10 to $12-19$ to 24 & $<0.056$ \\
\hline & & & & 13 to $18-19$ to 24 & $<1.000$ \\
\hline \multirow{7}{*}{ Social interaction } & \multirow{7}{*}{95.188} & \multirow{7}{*}{3} & \multirow{7}{*}{$<0.001$} & 6 to $9-10$ to 12 & $<0.003$ \\
\hline & & & & 6 to $9-13$ to 18 & $<0.001$ \\
\hline & & & & 6 to $9-19$ to 24 & $<0.001$ \\
\hline & & & & & \\
\hline & & & & 10 to $12-13$ to 18 & $<0.001$ \\
\hline & & & & 10 to $12-19$ to 24 & $<0.001$ \\
\hline & & & & 13 to $18-19$ to 24 & $<0.942$ \\
\hline \multirow{7}{*}{ Imitation } & \multirow{7}{*}{128.707} & \multirow{7}{*}{3} & \multirow{7}{*}{$<0.001$} & 6 to $9-10$ to 12 & $<0.006$ \\
\hline & & & & 6 to $9-13$ to 18 & $<0.001$ \\
\hline & & & & 6 to $9-19$ to 24 & $<0.001$ \\
\hline & & & & & \\
\hline & & & & 10 to $12-13$ to 18 & $<0.001$ \\
\hline & & & & 10 to $12-19$ to 24 & $<0.001$ \\
\hline & & & & 13 to $18-19$ to 24 & $<0.356$ \\
\hline \multirow{7}{*}{ Object permanence } & \multirow{7}{*}{132.283} & \multirow{7}{*}{3} & \multirow{7}{*}{$<0.001$} & 6 to $9-10$ to 12 & $<0.051$ \\
\hline & & & & 6 to $9-13$ to 18 & $<0.001$ \\
\hline & & & & 6 to $9-19$ to 24 & $<0.001$ \\
\hline & & & & & \\
\hline & & & & 10 to $12-13$ to 18 & $<0.008$ \\
\hline & & & & 10 to $12-19$ to 24 & $<0.001$ \\
\hline & & & & 13 to $18-19$ to 24 & $<0.001$ \\
\hline \multirow{7}{*}{ Play } & \multirow{7}{*}{136.551} & \multirow{7}{*}{3} & \multirow{7}{*}{$<0.001$} & 6 to $9-10$ to 12 & $<0.001$ \\
\hline & & & & 6 to $9-13$ to 18 & $<0.001$ \\
\hline & & & & 6 to $9-19$ to 24 & $<0.001$ \\
\hline & & & & & \\
\hline & & & & 10 to $12-13$ to 18 & $<0.001$ \\
\hline & & & & 10 to $12-19$ to 24 & $<0.001$ \\
\hline & & & & 13 to $18-19$ to 24 & $<0.294$ \\
\hline
\end{tabular}


Table 7. The Results of the Mann-Whitney U Test

\begin{tabular}{|c|c|c|}
\hline Skills & Standardized Test Statistics & $\mathbf{P}$ \\
\hline Eye contact & -0.704 & $<0.482$ \\
\hline Gestures & -2.621 & $<0.009$ \\
\hline Vocalization & -2.206 & $<0.027$ \\
\hline First words & -3.624 & $<0.001$ \\
\hline Facial expressions & -0.300 & $<0.764$ \\
\hline Behavior regulation & -1.468 & $<0.142$ \\
\hline Joint attention & -0.951 & $<0.342$ \\
\hline Social interaction & -2.154 & $<0.031$ \\
\hline Imitation & -2.846 & $<0.004$ \\
\hline Object permanence & -1.162 & $<0.245$ \\
\hline Play & -3.953 & $<0.001$ \\
\hline
\end{tabular}

Iranian Rehabilitation Journal

ity, which is another skill with cognitive bases, is remarkable and is consistent with Gopnik et al.'s study [82].

According to O'Grady and Dusing, play skill develops in children as they age and become more complicated. For example, exploratory kind of play decreases, but functional, representational, and symbolic plays increase in children as they grow up [83]. The results of studies conducted by Nwokah et al. [84], Casby [85], and Bruce et al. [86] are consistent with the present study.

In addition to the difference between the results of the age groups, children with a negative family history of speech-language disorders had higher communication skills checklist scores. This finding is consistent with other studies [25-28], such as the study conducted by Molini-Avejonas et al., which considered positive family history a risk factor for speech-language impairments in children [22].

Our findings revealed the statistically significant differences between the two genders in gesture, vocalization, first words, social interaction, imitation, and play. As Jacklin and Baker [30] and Eagly et al. [31] indicated in their papers, there are some differences in the acquisition of language and its basic skills between the girls and boys based on social factors. For instance, Bornstein et al. reported that Argentinian, French, and American mothers tend to have more exploratory plays with boys and more symbolic plays with girls. Also, they often vo- calize while playing exploratory plays with boys and use words and sentences while playing with girls [32, 33]. Besides, girls tend to have fewer exploratory games in comparison to boys. These social factors, which have some effects on girls and boys, might be a reason for the different performance of the two genders.

\section{Conclusion}

In conclusion, children develop their communicational skills in the prelinguistic stage as they grow up. In this regard, the scores of eye contact, gestures, vocalization, first words, facial expressions, behavior regulation, joint attention, social interaction, imitation, object permanence, and play are different between 6 to 9 months, 10 to 12 months, 13 to 18 months, and 19 to 24 months age groups. A positive family history of speech-language impairments also might be a risk factor for children's prelinguistic developmental issues. Furthermore, some prelinguistic abilities have different developmental patterns between girls and boys. We also faced some limitations in this study. Due to the spread of COVID-19, we used the convenience sampling method. Furthermore, the socioeconomic status of the families was not considered. It is suggested to conduct studies on families with different socioeconomic classes. 


\section{Ethical Considerations}

\section{Compliance with ethical guidelines}

The research protocol was approved by the Ethics Committee of the University of Social Welfare and Rehabilitation Sciences, Tehran (Code: IR.USWR. REC.1400.025).

\section{Funding}

This research did not receive grants from funding agencies in the public, commercial, or non-profit sectors.

\section{Authors' contributions}

All authors equally contributed to preparing this article.

\section{Conflict of interest}

The authors declared no conflicts of interest.

\section{Acknowledgments}

The authors wish to thank all participants in this study. The present paper was extracted from the Master's thesis of the first author in Speech-Language Pathology at the University of Social Welfare and Rehabilitation Sciences, Tehran, Iran.

\section{References}

[1] Määttä S, Laakso M-L, Ahonen T, Tolvanen A, Westerholm J, Aro T. Continuity from prelinguistic communication to later language ability: A follow-up study from infancy to early school age. Journal of Speech, Language, and Hearing Research. 2016; 59(6):1357-72. [DOI:10.1044/2016_JSLHRL-15-0209] [PMID]

[2] Bates EA. Explaining and interpreting deficits in language development across clinical groups: Where do we go from here? Brain and Language. 2004; 88(2):248-53. [DOI:10.1016/ S0093-934X(03)00102-0]

[3] Rescorla L. Age 17 language and reading outcomes in late-talking toddlers: Support for a dimensional perspective on language delay. Journal of Speech, Language, and Hearing Research 2009; 52(1):16-30. [DOI:10.1044/1092-4388(2008/07-0171)]

[4] Brooks R, Meltzoff A. The development of gaze following and its relation to language. Developmental Science. 2005; 8(6):535-43. [DOI:10.1111/j.1467-7687.2005.00445.x] [PMID] [PMCID]

[5] Bullowa M, Fidelholtz JL, Kessler AR. Infant vocalization: Communication before speech. In: Williams TR, editor. Socialization and communication in primary groups. Germany: De Gruyter Mouton; 2011. [DOI:10.1515/9783110802870.253]
[6] Crais E, Watson L, Baranek G. Use of gesture development in profiling children's prelinguistic communication skills. American Journal of Speech-Language Pathology. 2009; 18(1):95-108. [DOI:10.1044/1058-0360(2008/07-0041)]

[7] Renzi DT, Romberg AR, Bolger DJ, Newman RS. Two minds are better than one: Cooperative communication as a new framework for understanding infant language learning. Translational Issues in Psychological Science. 2017; 3(1):19-33 [DOI:10.1037/tps0000088]

[8] Tronick EZ. Emotions and emotional communication in infants. American Psychologist. 1989; 44(2):112-9. [DOI:10.1037/0003-066X.44.2.112]

[9] Watt N, Wetherby A, Shumway S. Prelinguistic predictors of language outcome at 3 years of age. Journal of Speech, Language, and Hearing Research. 2006; 49(6):1224-37. [DOI:10.1044/1092-4388(2006/088)]

[10] Shumway S, Wetherby AM. Communicative acts of children with autism spectrum disorders in the second year of life. Journal of Speech, Language, and Hearing Research. 2009; 52(5):1139-56. [DOI:10.1044/1092-4388(2009/07-0280)]

[11] Baillargeon R, Spelke ES, Wasserman S. Object permanence in five-month-old infants. Cognition. 1985; 20(3):191-208. [DOI:10.1016/0010-0277(85)90008-3]

[12] Frith CD, Wolpert DM, Meltzoff AN, Decety J. What imitation tells us about social cognition: A rapprochement between developmental psychology and cognitive neuroscience. Philosophical Transactions of the Royal Society of London Series B: Biological Sciences. 2003; 358(1431):491-500. [DOI:10.1098/ rstb.2002.1261] [PMID] [PMCID]

[13] Quinn S, Donnelly S, Kidd E. The relationship between symbolic play and language acquisition: A meta-analytic review. Developmental Review. 2018; 49:121-35. [DOI:10.1016/j. dr.2018.05.005

[14] Crais E, Ogletree BT. Prelinguistic communication development. In: Keen D, Meadan H, Brady NC, Halle JW, editors. Prelinguistic and minimally verbal communicators on the autism spectrum. 1th ed. Singapore: Springer; 2016. [DOI:10.1007/978-981-10-0713-2_2]

[15] Lüke C, Ritterfeld U, Grimminger A, Liszkowski U, Rohlfing KJ. Development of pointing gestures in children with typical and delayed language acquisition. Journal of Speech Language, and Hearing Research. 2017; 60(11):3185-97. [DOI:10.1044/2017_JSLHR-L-16-0129] [PMID]

[16] Orr E, Geva R. Symbolic play and language development. Infant Behavior and Development. 2015; 38:147-61. [DOI:10.1016/j.infbeh.2015.01.002] [PMID]

[17] Mohammed HO, Mahmoud NF. The early communicative skills among a sample of Egyptian infants and toddlers. The Egyptian Journal of Otolaryngology. 2020; 36:21. [DOI:10.1186/s43163-020-00023-3]

[18] Wetherby AM, Prizant BM. Communication and symbolic behavior scales: Developmental profile,, 1st normed ed. Baltimore, MD, US: Paul H Brookes Publishing Co.; 2002. [DOI:10.1037/t11529-000]

[19] Fasolo M, Majorano M, D'Odorico L. Babbling and first words in children with slow expressive development. Clinical Linguistics \& Phonetics. 2008; 22(2):83-94. [DOI:10.1080/02699200701600015] [PMID] 
[20] Neils J, Aram DM. Family history of children with developmental language disorders. Perceptual and Motor Skills. 1986; 63(2 Pt 1):655-8. [DOI:10.2466/pms.1986.63.2.655] [PMID]

[21] Eriksson M, Marschik PB, Tulviste T, Almgren M, Pérez Pereira M, Wehberg S, et al. Differences between girls and boys in emerging language skills: Evidence from 10 language communities. The British Journal of Developmental Psychology. 2012; 30(Pt 2):326-43. [DOI:10.1111/j.2044835X.2011.02042.x] [PMID]

[22] Molini-Avejonas DR, Ferreira LV, Amato CAdLH. Risk factors for speech-language pathologies in children. In: Dipper LT, Pritchard M, Győrfi A, Tumanova TV, Filicheva T, Pavez MM, editors. Advances in speech-language pathology. London.: IntechOpen; 2017. [DOI:10.5772/intechopen.70107]

[23] Sunderajan T, Kanhere S. Speech and language delay in children: Prevalence and risk factors. Journal of Family Medicine and Primary Care. 2019; 8(5):1642-6. [DOI:10.4103/jfmpc. jfmpc_162_19] [PMID] [PMCID]

[24] Saeed HT, Abdulaziz B, Al-Daboon SJ. Prevalence and risk factors of primary speech and language delay in children less than seven years of age. Journal of Community Medicine \& Health Education. 2018; 8(2):608. [DOI:10.4172/21610711.1000608

[25] Conti-Ramsden G, Durkin K. What factors influence language impairment considering resilience as well as risk. Folia Phoniatrica et Logopaedica. 2015; 67(6):293-9. [DOI:10.1159/000444750] [PMID] [PMCID]

[26] Bishop DVM, North T, Donlan C. Genetic basis of specific language impairment: Evidence from a twin study. Developmental Medicine \& Child Neurology. 1995; 37(1):56-71. [DOI:10.1111/j.1469-8749.1995.tb11932.x] [PMID]

[27] Choudhury N, Benasich AA. A family aggregation study. Journal of Speech, Language, and Hearing Research. 2003; 46(2):261-72. [DOI:10.1044/1092-4388(2003/021)]

[28] Bishop DVM. The role of genes in the etiology of specific language impairment. Journal of Communication Disorders. 2002; 35(4):311-28. [DOI:10.1016/S0021-9924(02)00087-4]

[29] Lutchmaya S, Baron-Cohen S, Raggatt P. Foetal testosterone and vocabulary size in 18- and 24-month-old infants. Infant Behavior and Development. 2001; 24(4):418-24. [DOI:10.1016/S0163-6383(02)00087-5]

[30] Bussey K, Bandura A. Social cognitive theory of gender development and differentiation. Psychological Review. 1999; 106(4):676-713. [DOI:10.1037/0033-295X.106.4.676] [PMID]

[31] Eagly AH, Mitchell AA. Social role theory of sex differences and similarities: Implications for the sociopolitical attitudes of women and men. In: Paludi MA, editor. Praeger guide to the psychology of gender. United States: Praeger Publishers; 2004. https://books.google.com/books/about/ Praeger_Guide_to_the_Psychology_of_Gende.html?id=1AtAAAAMAAJ\&source=kp_book_description

[32] Bornstein MH, Haynes OM, Pascual L, Painter KM, Galperín C. Play in two societies: Pervasiveness of process, specificity of structure. Child Development. 1999; 70(2):317-31. [DOI:10.1111/1467-8624.00024] [PMID]

[33] Suizzo M-A, Bornstein MH. French and European American child-mother play: Culture and gender considerations.
International Journal of Behavioral Development. 2006; 30(6):498-508. [DOI:10.1177/0165025406071912]

[34] Ellis H. Man and woman: A study of human secondary sexual characters. London: A \& C Black; 1894. https:// books.google.com/books/about/Man_Woman.html?id=zOKAAAAIAAJ

[35] Arden R, Plomin R. Sex differences in variance of intelligence across childhood. Personality and Individual Differences. 2006; 41(1):39-48. [DOI:10.1016/j.paid.2005.11.027]

[36] Fisher SE, Vargha-Khadem F, Watkins KE, Monaco AP, Pembrey ME. Localisation of a gene implicated in a severe speech and language disorder. Nature Genetics. 1998; 18(2):168-70. [DOI:10.1038/ng0298-168] [PMID]

[37] Chen XS, Reader RH, Hoischen A, Veltman JA, Simpson $\mathrm{NH}$, Francks C, et al. Next-generation DNA sequencing identifies novel gene variants and pathways involved in specific language impairment. Scientific Reports. 2017; 7:46105. [DOI:10.1038/srep46105] [PMID] [PMCID]

[38] Graham SA, Fisher SE. Understanding language from a genomic perspective. Annual Review of Genetics. 2015; 49:131-60. [DOI:10.1146/annurev-genet-120213-092236] [PMID]

[39] Simpson NH, Addis L, Brandler WM, Slonims V, Clark A, Watson J, et al. Increased prevalence of sex chromosome aneuploidies in specific language impairment and dyslexia. Developmental Medicine \& Child Neurology. 2014; 56(4):346-53. [DOI:10.1111/dmcn.12294] [PMID] [PMCID]

[40] Wermke K, Quast A, Hesse V. From melody to words: The role of sex hormones in early language development Hormones and Behavior. 2018; 104:206-15. [DOI:10.1016/j. yhbeh.2018.03.008] [PMID]

[41] Jalilevand N, Ebrahimipur M, Purqarib J. Mean length of utterance and grammatical morphemes in speech of two Farsi-speaking children. Auditory and Vestibular Research. 2012; 21(2):96-108. https://avr.tums.ac.ir/index.php/avr/ article/view/472

[42] Sheibani F, Ghoreishi ZS, Nilipour R, Pourshahbaz A Zamani SM. Validity and Reliability of a Language Development Scale for Persian-speaking Children Aged 2-6 Years. Iranian Journal of Medical Sciences. 2020; 45(4):259-68. [DOI 10.30476/ijms.2020.72538.0] [PMCID] [PMID]

[43] Samadi H, Perkins MR. P-LARSP: A developmental language profile for Persian. Clinical Linguistics \& Phonetics. 1998; 12(2):83-103. [DOI:10.3109/02699209808985215]

[44] Soraya M, Mahmoudi Bakhtiyari B, Badiee Z, Kazemi Y, Soleimani B. A comparative study of size of expressive lexicon in prematurely born children with full-term 18-36 month's children. Auditory and Vestibular Research. 2012; 21(1:76-82. https://avr.tums.ac.ir/index.php/avr/article/view/453

[45] Mahmoudi Bakhtiyari B, Soraya M, Badiee Z, Kazemi Y, Soleimani B. [The size of expressive lexicon in 18-to-36month-old children raised in farsi-speaking families: A comparative study (Persian)]. Journal of Research in Rehabilitation Sciences. 2011; 7(5):681-7. [DOI:10.22122/jrrs.v7i5.190]

[46] Joneghani MS, Kazemi Y, Sima Shirazi T. [A validation study of the gestures section of the macarthur-bates Communicative Development Inventory (CDI)-infant form for Persian-speaking infants in Isfahan (Persian)]. Middle East- 
ern Journal Of Disability Studies. 2017; 7. https://www.sid. ir/en/journal/ViewPaper.aspx?id=551483

[47] Fotuhi M, Yadegari F, Teymouri R. Vowels development in babbling of typically developing 6-to-12-month old Persianlearning infants. Logopedics Phoniatrics Vocology. 2017 42(3):118-25. [DOI:10.1080/14015439.2016.1221446] [PMID]

[48] Babaei Z, Zarifian T, Ashtari A, Bakhshi E. [Study of deictic gesture in normally developing Persian- speaking children between 12 to 18 months old: A longitudinal study (Persian)] Koomesh. 2017; 19(4):894-900. https://www.cabdirect.org/ cabdirect/abstract/20183090847

[49] Babaei Z, Zarifian T, Ashtari A, Bakhshi E. [Development of communicative functions in normal Persian-speaking children from 12 to 18 months of age: A longitudinal study (Persian)]. Archives of Rehabilitation. 2020; 21(2):220-35. [DOI:10.32598/RJ.21.2.2956.1]

[50] Vameghi R, Sajedi F, Kraskian Mojembari A, Habiollahi A, Lornezhad HR, Delavar B. Cross-cultural adaptation, validation and standardization of Ages and Stages Questionnaire (ASQ) in Iranian children. Iranian Journal of Public Health. 2013; 42(5):522-8. [PMCID]

[51] Oryadi-Zanjani MM. Development of the childhood nonverbal communication scale. Journal of Autism and Developmental Disorders. 2020; 50(4):1238-48. [DOI:10.1007/s10803019-04356-8] [PMID]

[52] Bayat N, Ashatri A, Vahedi M. Development of communication skills checklist of 6 to 24-month old Persian children: Validity and reliability [MSc. Thesis]. University of Social Welfare and Rehabilitation Sciences; 2021.

[53] Rodrigues IB, Adachi JD, Beattie KA, Lau A, MacDermid JC. Determining known-group validity and test-retest reliability in the PEQ (personalized exercise questionnaire). BMC Musculoskeletal Disorders. 2019; 20(1):373. [DOI:10.1186/ s12891-019-2761-3] [PMID] [PMCID]

[54] McKight PE, Najab J. Kruskal-Wallis Test. In: Weiner LB, Craighead WE, editors. The corsini encyclopedia of psychology. 4th ed. United States: John Wiley \& Sons; 2010. [DOI:10.1002/9780470479216.corpsy0491]

[55] Dawson G, Osterling J, Meltzoff AN, Kuhl P. Case study of the development of an infant with autism from birth to two years of age. Journal of Applied Developmental Psychology. 2000; 21(3):299-313. [DOI:10.1016/S0193-3973(99)00042-8]

[56] Berger J, Cunningham CC. The development of eye contact between mothers and normal versus Down's syndrome infants. Developmental Psychology. 1981; 17(5):678-89. [DOI:10.1037/0012-1649.17.5.678]

[57] Niedźwiecka A. Look me in the eyes: Mechanisms underlying the eye contact effect. Child Development Perspectives. 2020; 14(2):78-82. [DOI:10.1111/cdep.12361]

[58] Masur EF. Gestural development, dual-directional signaling, and the transition to words. Journal of Psycholinguistic Research. 1983; 12(2):93-109. [DOI:10.1007/BF01067406]

[59] Iverson JM, Capirci O, Caselli MC. From communication to language in two modalities. Cognitive Development. 1994; 9(1):23-43. [DOI:10.1016/0885-2014(94)90018-3]
[60] Bakeman R, Adamson LB. Coordinating attention to people and objects in mother-infant and peer-infant interaction. Child Development. 1984;55(4):1278-89. [DOI:10.2307/1129997] [PMID]

[61] Colonnesi C, Stams GJJM, Koster I, Noom MJ. The relation between pointing and language development: A meta-analysis. Developmental Review. 2010; 30(4):352-66. [DOI:10.1016/j.dr.2010.10.001]

[62] Bates E. Cognition and communication from 9 to 13 months: Correlational findings. In: Bates E, Bretherton I, Benigni L, editors. The emergence of symbols: Cognition and communication in infancy. Cambridge: Academic Press; 1979. [DOI:10.1016/B978-0-12-081540-1.50009-0]

[63] Crais E, Douglas DD, Campbell CC. The intersection of the development of gestures and intentionality. Journal of Speech, Language, and Hearing Research. 2004; 47(3):678-94. [DOI:10.1044/1092-4388(2004/052)]

[64] Tomasello M, Carpenter M, Liszkowski U. A new look at infant pointing. Child Development. 2007; 78(3):705-22. [DOI:10.1111/j.1467-8624.2007.01025.x] [PMID]

[65] Davis BL, Macneilage PF. Organization of babbling: A case study. Language and Speech. 1994; 37(Pt 4):341-55. [DOI:10.1 177/002383099403700401] [PMID]

[66] Brooks PJ, Kempe V. Language development. New York: John Wiley \& Sons; 2012. https://books. google.com/books/about/Language_Development. html?id=SpklFv432AcC\&source=kp_book_description

[67] Tardif T, Fletcher P, Liang W, Zhang Z, Kaciroti N, Marchman VA. Baby's first 10 words. Developmental Psychology. 2008; 44(4):929-38. [DOI:10.1037/0012-1649.44.4.929] [PMID]

[68] Rudolph JM, Leonard LB. Early language milestones and specific language impairment. Journal of Early Intervention. 2016; 38(1):41-58. [DOI:10.1177/1053815116633861]

[69] Bremner JG, Fogel A. Blackwell handbook of infant development. New York: John Wiley \& Sons; 2009. https:/ / books. google.com/books/about/Blackwell_Handbook_of_Infant_ Development.html?id=0uG00awzXwgC

[70] Kauschke C. Normal and delayed lexical acquisition in German. Proceedings of the International Conference: Early Lexicon Acquisition: Normal and Pathological; 2001. http:// www.christina-kauschke.de/_site/pdf/Kauschke_Lyon.pdf

[71] Herba C, Phillips M. Annotation: Development of facial expression recognition from childhood to adolescence: Behavioural and neurological perspectives. Journal of Child Psychology and Psychiatry. 2004; 45(7):1185-98. [DOI:10.1111/j.1469-7610.2004.00316.x] [PMID]

[72] Cole PM. Children's spontaneous control of facial expression. Child Development. 1986; 57(6):1309-21. [DOI:10.2307/1130411]

[73] McClure EB. A meta-analytic review of sex differences in facial expression processing and their development in infants, children, and adolescents. Psychological Bulletin. 2000; 126(3):424-53. [DOI:10.1037/0033-2909.126.3.424] [PMID]

[74] Thompson J. Development of facial expression of emotion in blind and seeing children. Michigan: University Press; 1941. https://books.google.com/books/about/Development_of_ Facial_Expression_of_Emot.html?id=CI_F17FEFWcC 
[75] Mundy P, Block J, Delgado C, Pomares Y, Van Hecke AV, Parlade MV. Individual differences and the development of joint attention in infancy. Child Development. 2007; 78(3):938-54. [DOI:10.1111/j.1467-8624.2007.01042.x] [PMID] [PMCID]

[76] Carpenter M, Nagell K, Tomasello M. Social cognition, joint attention, and communicative competence from 9 to 15 months of age. Monographs of the Society for Research in Child Development. 1998; 63(4):i-vi, 1-143. [PMID]

[77] Papousek H, Papousek M. Cognitive aspects of preverbal social interaction between human infants and adults. Ciba Foundation Symposium. 1975; (33):241-69. [DOI:10.1002/9780470720158.ch14]

[78] Meltzoff AN, Moore MK. Persons and representation Why infant imitation is important for theories of human development. In: Nadel J, Butterworth G, editors. Imitation in infancy. Cambridge studies in cognitive perceptual development. New York: Cambridge University Press; 1999. https:// psycnet.apa.org/record/1999-02466-000

[79] Jones SS. The development of imitation in infancy. Philosophical Transactions of the Royal Society of London Series B, Biological Sciences. 2009; 364(1528):2325-35. [DOI:10.1098/ rstb.2009.0045] [PMID] [PMCID]

[80] Wang Z, Williamson RA, Meltzoff AN. Imitation as a mechanism in cognitive development: A cross-cultural investigation of 4-year-old children's rule learning. Frontiers in Psychology. 2015; 6:562. [DOI:10.3389/fpsyg.2015.00562]

[81] Oostenbroek J, Suddendorf T, Nielsen M, Redshaw J, Kennedy-Costantini S, Davis J, et al. Comprehensive longitudinal study challenges the existence of neonatal imitation in humans. Current Biology. 2016; 26(10):1334-8. [DOI:10.1016/j. cub.2016.03.047] [PMID]

[82] Gopnik A, Meltzoff AN. Early semantic developments and their relationship to object permanence, means-ends understanding, and categorization. In: Nelson KE, van Kleeck A, editors. Children's language. 1th ed. New York: Psychology Press; 2021. [DOI:10.4324/9781315792668-9]

[83] O'Grady MG, Dusing SC. Reliability and validity of playbased assessments of motor and cognitive skills for infants and young children: A systematic review. Physical Therapy. 2015; 95(1):25-38. [DOI:10.2522/pti.20140111] [PMID]

[84] Nwokah E, Hsu HC, Gulker H. The use of play materials in early intervention: The dilemma of poverty. American Journal of Play. 2013; 5(2):187-218. https:/ / eric.ed.gov/?id=EJ1003950

[85] Casby MW. Developmental assessment of play: A model for early intervention. Communication Disorders Quarterly. 2003; 24(4):175-83. [DOI:10.1177/15257401030240040301]

[86] Bruce B, Kornfalt R, Radeborg K, Hansson K, Nettelbladt U. Identifying children at risk for language impairment: Screening of communication at 18 months. Acta Paediatrica 2003; 92(9):1090-5. [DOI:10.1080/08035250310004414] [PMID] 
This Page Intentionally Left Blank 